\title{
The Potential Impact of Smog Spell on Humans' Health Amid COVID-19 Rages
}

\author{
Ammar Javed ${ }^{1,+}\left(\mathbb{D}\right.$, Farheen Aamir ${ }^{1, \dagger}{ }^{+}$Umar Farooq Gohar ${ }^{1}\left(\mathbb{D}\right.$, Hamid Mukhtar ${ }^{1} \oplus$, Muhammad Zia-UI-Haq ${ }^{2, *}$, \\ Modhi O. Alotaibi ${ }^{3}\left(\mathbb{D}\right.$, May Nasser Bin-Jumah ${ }^{3,4}$, Romina Alina Marc (Vlaic) ${ }^{5, *(1)}$ and Oana Lelia Pop ${ }^{6}$
}

Citation: Javed, A.; Aamir, F.; Gohar, U.F.; Mukhtar, H.; Zia-UI-Haq, M.; Alotaibi, M.O.; Bin-Jumah, M.N.; Marc (Vlaic), R.A.; Pop, O.L. The Potential Impact of Smog Spell on Humans' Health Amid COVID-19 Rages. Int. J. Environ. Res. Public Health 2021, 18, 11408. https:// doi.org/10.3390/ijerph182111408

Academic Editor: Dirga

Kumar Lamichhane

Received: 14 September 2021

Accepted: 28 October 2021

Published: 29 October 2021

Corrected: 5 December 2022

Publisher's Note: MDPI stays neutral with regard to jurisdictional claims in published maps and institutional affiliations.

Copyright: (c) 2021 by the authors. Licensee MDPI, Basel, Switzerland. This article is an open access article distributed under the terms and conditions of the Creative Commons Attribution (CC BY) license (https:/ / creativecommons.org/licenses/by/ $4.0 /)$.
1 Institute of Industrial Biotechnology, Government College University Lahore, Lahore 54000, Pakistan; ammarjaved94@gmail.com (A.J.); farheenaamir15@gmail.com (F.A.); dr.mufgohar@gcu.edu.pk (U.F.G.); hamidmukhtar@gcu.edu.pk (H.M.)

2 Office of Research, Innovation \& Commercialization, Lahore College for Women University, Lahore 54000, Pakistan

3 Biology Department, College of Science, Princess Nourah Bint Abdulrahman University, Riyadh 11671, Saudi Arabia; mouotaebe@pnu.edu.sa (M.O.A.); mnbinjumah@pnu.edu.sa (M.N.B.-J.)

4 Environment and Biomaterial Unit, Health Sciences Research Center, Princess Nourah Bint Abdulrahman University, Riyadh 11671, Saudi Arabia

5 Food Engineering Department, Faculty of Food Science and Technology, University of Agricultural Sciences and Veterinary Medicine, 400372 Cluj-Napoca, Romania

6 Department of Food Science, University of Agricultural Science and Veterinary Medicine, 400372 Cluj-Napoca, Romania; oana.pop@usamvcluj.ro

* Correspondence: ahirzia@gmail.com (M.Z.-U.-H.); romina.vlaic@usamvcluj.ro (R.A.M.)

+ These authors contributed equally to this paper.

\begin{abstract}
Rapid and unchecked industrialization and the combustion of fossil fuels have engendered a state of fear in urban settlements. Smog is a visible form of air pollution that arises due to the over-emissions of some primary pollutants like volatile organic compounds (VOCs), hydrocarbons, $\mathrm{SO}_{2}, \mathrm{NO}$, and $\mathrm{NO}_{2}$ which further react in the atmosphere and give rise to toxic and carcinogenic secondary smog components. Smog reduces the visibility on roads and results in road accidents and cancellation of flights. Uptake of primary and secondary pollutants of smog is responsible for several deleterious diseases of which respiratory disorders, cardiovascular dysfunction, neurological disorders, and cancer are discussed here. Children and pregnant women are more prone to the hazards of smog. The worsening menace of smog on one hand and occurrence of pandemic i.e., COVID-19 on the other may increase the mortality rate. But the implementation of lockdown during pandemics has favored the atmosphere in some ways, which will be highlighted in the article. On the whole, the focus of this article will be on the dubious relationship between smog and coronavirus.
\end{abstract}

Keywords: air pollution; COVID-19; photochemical smog; respiratory disorders

\section{Introduction}

The word smog is an amalgamation of two words, 'smoke' and 'fog'. Fog is reckoned as a visible low lying cloud, made up of small water droplets or ice crystals [1]. In 1905, H. A. Des Voeux used the term 'smog' to define the atmospheric conditions of many towns in Britain. In 1911, this word became famous when H. A. Des Voeux reported 1000 deaths in his paper 'Smoke and Fog' due to 'smoke-fog' in Edinburgh and Glasgow [2]. Nowadays, Lahore, Faisalabad, Delhi, Beijing, Los Angles, Mexico, and London are mostly affected by the smog [3-9].

Currently, various studies have provided knowledge to the general population about the relationship between smog and its adverse effects on human health. Earlier researchers had confirmed that health effects are related to persons' age, health, and socioeconomic status [10]. However, the impact of smog is also influenced by its time of exposure. The risk of long-term exposure is much higher than that of short-term exposure. Both the 
long-term unceasing exposure and short-term peak do not have the same consequences and they follow different dynamics. The effects range from short-term irritation in the trachea to long-term genetic mutations. However, some recent studies have observed a link between adverse mortality and short-term exposure to smog [11]. These adverse health effects have a broad array from subclinical effects like irritation in the trachea to long-term genetic mutations and premature deaths. Some of the major diseases which are harbored by smog are respiratory diseases (asthma, coughing, and bronchiolitis), cardiovascular disease, neurological disorders, cancer, infant health, low birth weight, and other problems like eye irritation and breathing difficulties [12-15].

On the other hand, the novel coronavirus outbreak has shaken the world. It engulfed the whole world within a year. The root cause of this pandemic i.e., SARS-CoV-2 (Severe acute respiratory syndrome coronavirus-2) is transmissible from humans to humans. It targets the respiratory tract of humans, attaches with the angiotensin-converting enzyme-2 (ACE2), and down-regulates its production to cause severe respiratory illnesses. Although the mortality rate of coronavirus disease of 2019 (COVID-19) is less than $10 \%$ together with smog, the increase in fatality can be observed because both target the respiratory tract of humans [16]. In elderly people, coronavirus invasion is facilitated as immune responses are weakened by age and smog [17]. Together they may worsen the disease and can lead to hospitalization and eventually death occurs [18] as shown in Figure 1. Studies have backed the hypothesis that components of air pollution like nitrogen dioxide $\left(\mathrm{NO}_{2}\right)$ and particulate matter (PM) cause the excessive production of the Angiotensin-converting enzyme-2 (ACE2) which is the binding target for SARS-CoV-2 [19-21]. This increased production increases the susceptibility towards COVID-19. Thus the combination of coronavirus and air pollution can exacerbate the situation. The regions like China, India, and the USA a positive correlation is observed between COVID-19 mortality and high air pollution. This aggravates the need to control air pollution to reduce coronavirus cases where they share common hotspots [22,23]. However, there is another aspect of this pandemic. Due to the pandemic, people are locked in their houses to avoid SARS-CoV-2 infection. This reduction in human activities has a positive has brought a positive impact on nature like less water, air, and noise pollution. The lockdown periods have also prevented several deaths due to a reduction in air pollutants [24]. The purpose of the paper is to highlight the negative aspects of the relation of smog with the current coronavirus pandemic. Along with negative aspects, positive aspects of the lockdown on air pollution are also discussed in the paper.

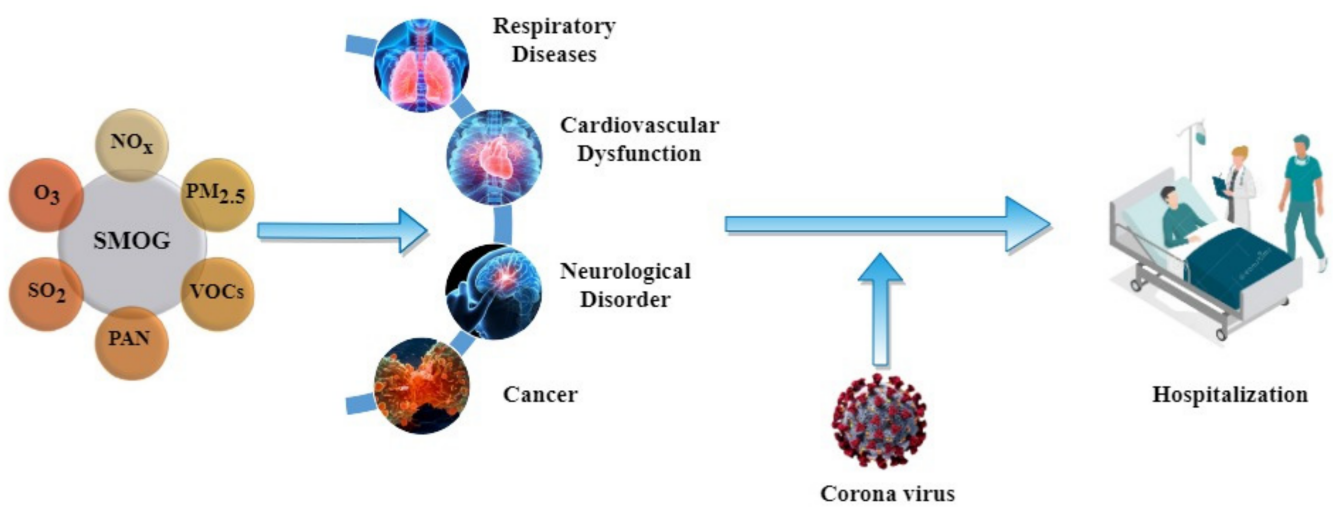

Figure 1. Relationship between COVID-19 and smog.

\section{Research Methodology}

\subsection{Identifying the Research Question}

The following questions are established to address the relation of smog with coronavirus disease.

1. What are the components of the smog that are of concern during the pandemic?

2. Does amalgamation of coronavirus and smog increase the health risks? 
3. Does the COVID-lockdown bring any positive effects on the air quality?

\subsection{Finding and Selecting the Relevant Studies}

To draft this review, we have searched PubMed for the articles that discussed the relationship between smog and coronavirus disease and have to obtain the most relevant studies using simple keywords "Smog", "Air pollution", "Coronavirus" and "COVID-19". We have also gone through the references section of these articles to select the pertinent publications.

\section{Smog}

The 20th century marks some of the disastrous events related to smog. In the 1930s, the areas of Liège and Huy alongside River Meuse were hubs of industries in Continental Europe. After the industrial revolution fertilizer, glass, zinc smelters, steelworks, and explosive manufacturing plants were established in these areas [25]. At the end of the year, these areas were shrouded by a thick fig for five days (1-5 December). Within 3 days hundreds of people contracted the signs and symptoms of respiratory diseases. The government was baffled completely after the death of 63 people. On the 6th of December, smog disappeared completely with improvement in respiratory troubles [26].

On the 28th of November 1939, dwellers of ST. LOUIS faced a thick smog for over a month as they were burning cheap coal to keep themselves warm from cold weather. Kings-highway and neighboring areas were completely covered by darkness during the daytime. That day is attributed as 'Black Tuesday' in history. ST. LOUIS faced smog events later in the next year after which the authorities took proper actions to resolve the pollution issue [27-29].

On October 26, 1948 fog mixed with industrial pollutants engulfed the atmosphere of Donora, Pennsylvania [30]. Donora Zinc Works, part of US Steel was blamed by the authorities as a major contributor to smog. About 5000-7000 residents became ill, 400 were hospitalized and 20 people died. After five days on 31st October 1948, the smog was dispersed by the rain [31]. Donora also faced small smog events on the 4th and 14th of October, 1923 [32]. After the events, the Donora Zinc Works was shut down [31].

In 1952, London (England's capital) was engulfed for five days by the lethal black haze called, Great London Smog of 1952 [33]. In December residents of London burned the high sulfur coal [2] to keep themselves warm. This black smoke escaped from their chimneys and mixed with fog [34]. Then this smog cooled by air covered the atmosphere and blocked the sunlight. This black haze proved to be hazardous when converted into sulfur dioxide and sulfuric acid (i.e., corrosive) and affected the eyes, skin, respiratory and cardiac systems of Londoners [33]. This smog caused an increase in hospitalization (48\%), respiratory diseases (163\%), and asthma in newborn children (20\%) [35].

Historical events are discussed to bring an insight into the occurrence of the smog. It helps to determine the possible season, time, or region in which smog is most prevalent. If one knows the possible time of occurrence of smog during the pandemic, then measures can be taken accordingly.

Different types of smog contribute to air pollution. They are London smog (high content of sulfur oxides), Polish smog $\left(\mathrm{PM}_{10}, \mathrm{PM}_{2.5}, \mathrm{PM}_{1}\right.$, and various polycyclic aromatic hydrocarbons such as benzo-pyrene), photochemical smog (nitrogen oxides, ozone, hydrocarbons, and VOCs) as shown in Figure 2, and the natural smog released from volcanoes ( $\mathrm{CO}, \mathrm{CO}_{2}, \mathrm{SO}, \mathrm{H}_{2}$, and $\mathrm{H}_{2} \mathrm{~S}$ ) and plants (hydrocarbons and VOCs) [1,36-39]. Table 1 shows the distinctive features of different types of smog. 


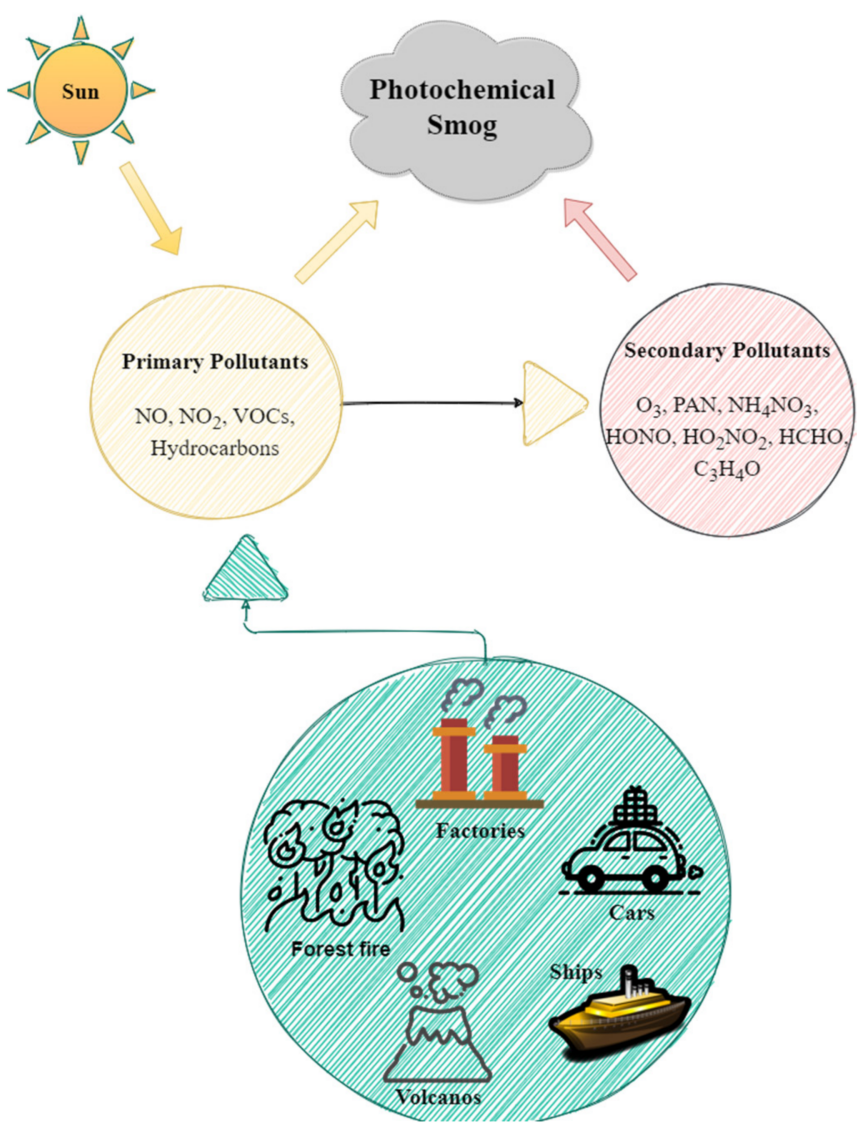

Figure 2. The activities of erupting volcanoes, traffic emissions, forest fires, general combustion, mining, agriculture are directly or indirectly involved in the production of primary pollutants like $\mathrm{NO}, \mathrm{NO}_{2}, \mathrm{VOCs}$, and hydrocarbons which are major forerunners of smog. These primary pollutants undergo chemical reactions in presence of sunlight to form secondary pollutants like formaldehyde, peroxyacetyl nitrate (PAN), and $\mathrm{O}_{3}[40,41]$. Both primary and secondary pollutants then concoct smog.

Table 1. Distinctive features between London, Photochemical and Natural smog.

\begin{tabular}{|c|c|c|c|c|c|}
\hline Characters & $\begin{array}{l}\text { London Smog } \\
\text { (Sulfurous Smog) }\end{array}$ & Polish Smog & $\begin{array}{l}\text { Photochemical } \\
\text { Smog (Los } \\
\text { Angeles Smog or } \\
\text { Summer Smog) }\end{array}$ & Natural Smog & References \\
\hline Definition & $\begin{array}{l}\text { Develops due to } \\
\text { high concentration } \\
\text { of sulfur oxides in } \\
\text { the air }\end{array}$ & $\begin{array}{l}\text { When the } \\
\text { temperature drops, } \\
\text { inversion takes } \\
\text { place and a } \\
\text { low-level cloud of } \\
\text { pollutants form a } \\
\text { dusty cloud }\end{array}$ & $\begin{array}{l}\text { It is produced } \\
\text { when sunlight } \\
\text { reacts with oxides } \\
\text { of nitrogen or at } \\
\text { least one } \mathrm{VOC}^{1}\end{array}$ & $\begin{array}{l}\text { It may result due to volcanoes } \\
\text { also known as acid smog (vog) } \\
\text { and by plants i.e., natural } \\
\text { sources of hydrocarbons and } \\
\text { volatile organic compounds }\end{array}$ & {$[36,42-44]$} \\
\hline Occurrence & $\begin{array}{l}\text { It occurs in cold, } \\
\text { humid climates }\end{array}$ & $\begin{array}{l}\text { It occurs in the } \\
\text { winter seasons }\end{array}$ & $\begin{array}{l}\text { It occurs in a } \\
\text { warm, dry, and } \\
\text { sunny climate }\end{array}$ & $\begin{array}{l}\text { It occurs mostly in warm, } \\
\text { humid, and summer climate }\end{array}$ & {$[36,37,45,46]$} \\
\hline Effects & $\begin{array}{l}\text { It irritates the eyes, } \\
\text { causes bronchitis } \\
\text { and lung problems }\end{array}$ & $\begin{array}{l}\text { It affects the lungs, } \\
\text { causes asthma and } \\
\text { cardiovascular } \\
\text { diseases }\end{array}$ & $\begin{array}{l}\text { It irritates the eyes, } \\
\text { causes obstructive } \\
\text { pulmonary disease, } \\
\text { cardiovascular } \\
\text { disease, and } \\
\text { asthma. }\end{array}$ & $\begin{array}{l}\text { Irritation and inflammation of } \\
\text { eyes, dry cough, anterior } \\
\text { uveitis, breathing difficulties, } \\
\text { asthma, subconjunctival } \\
\text { hemorrhage. }\end{array}$ & {$[45,47-49]$} \\
\hline
\end{tabular}

\footnotetext{
${ }^{1}$ VOC: Volatile organic compound.
} 


\section{Some Major Smog Affected Populations}

Smog has affected developing as well as under-developing countries likewise. The air quality of any region is estimated by Air Quality Index (AQI). The more the AQI of a region more is pollution in the environment. The AQI values are compared with the units described in Figure 3. There are environment protection agencies that work for the improvement of air quality in the region because it affects nature as well as humans. Therefore, the implication of these standards and regulations during a pandemic is important as they help to monitor the air quality of different regions. These standards make sure that pollutants concentrations do not cross the threshold levels i.e., maximum permitted level (MPL), and if some have already crossed that limit then how could we reduce their concentration to MPLs. Air pollution has become a global problem but we can see that policies regarding control of air pollution vary from region to region. Developed countries like the United States (US) and European Union (EU) have adopted more advanced technologies while developing countries like India and China have just started to build their legislation regarding air pollution.

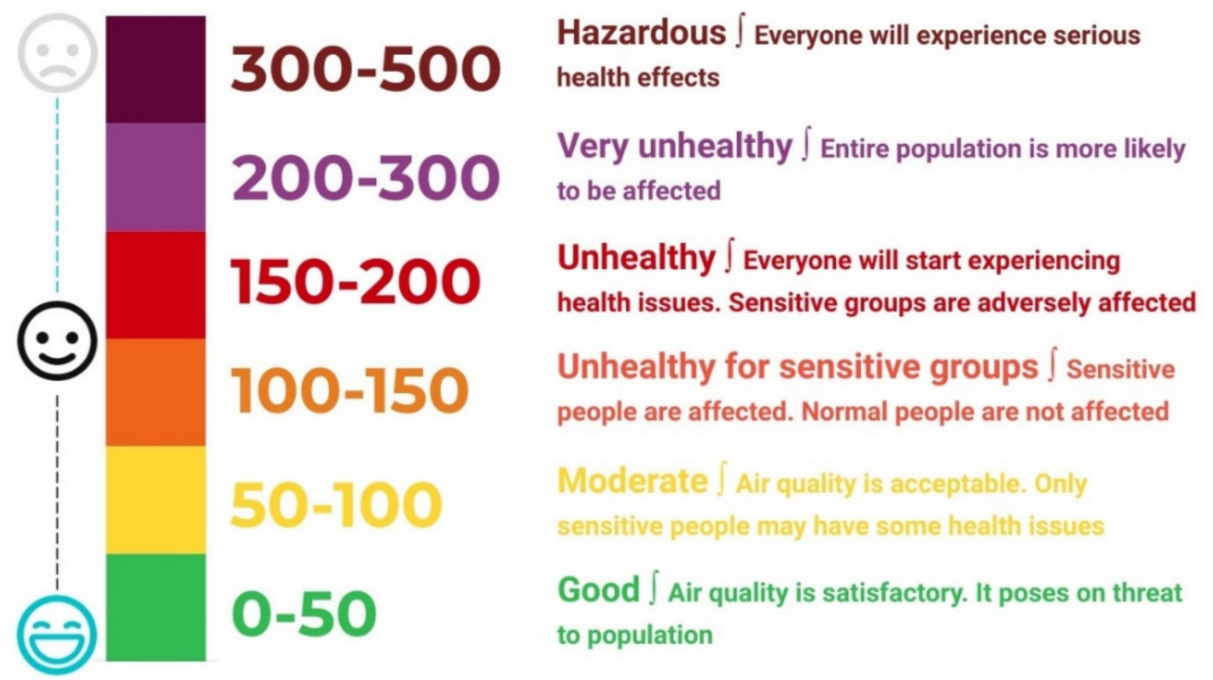

Figure 3. Air Quality Index Chart.

\subsection{China}

Air pollution has become a most concerning affair in China. Urbanization is considered the most detrimental cause of air pollution in which rural and agricultural land is converted to urban and non-agricultural land. Moreover, natural habitats are metamorphosed into cities. The enormously increasing Chinese economy, industrialization, and urbanization come at the cost of severe air pollution especially smog pollution [41]. After smoking, high blood pressure, and dietary risks, ambient $\mathrm{PM}_{2.5}$, and $\mathrm{PM}_{10}$ have become the fourth leading cause of death in China [50]. Nonetheless, the population affected by the recent events of air pollutions in China is phenomenal. Each year 350,000 to 400,000 deaths are attributed to air pollution in China [51]. Beijing faced multiple periods of prolonged air pollution in January 2013. The $\mathrm{PM}_{2.5}$ was calculated 32 times higher in Beijing (i.e., $800 \mathrm{mg} / \mathrm{m}^{3}$ ) than that recommended by World Health Organization (WHO) (i.e., $23 \mathrm{mg} / \mathrm{m}^{3}$ ) [52]. Similarly, another episode of smog stuck in Beijing for six days in February 2014. These smog spells affected not only Beijing but also nearby cities forcing the people to stay indoors to prevent adverse health effects [53]. The air quality index (AQI) is the unit used to measure the quality of air in a particular region. The AQI between 0 and 50 is considered good, 50 to 100 is moderate while 101 to onwards is considered unhealthy. Shahecheng (156), Nantong (140), Luancheng (134), Wuda (133), Handan (132), Yangliuqing (127), Dawakou (124), Yigou (122), and Zibo (119) are currently the most polluted cities of China [54]. Being an industrial country China has begun to endorse the policies regarding control of air 
pollution. Even after the implementation of the Action Plan, 2013 as a strategy to control air pollution, the levels of smog in the atmosphere are still concerning [55]. The evolution of Chinese air pollution control legislation and the standard sets for air pollutants are described in Tables 2 and 3.

Table 2. Evolution of Chinese legislation for Air pollution control [56].

\begin{tabular}{|c|c|c|}
\hline Year & Law or Action & Description \\
\hline 1979 & Environmental Protection Law & $\begin{array}{l}\text { First legislation related to environmental pollution } \\
\text { was established }\end{array}$ \\
\hline 1987 & $\begin{array}{l}\text { Air pollution prevention and } \\
\text { control Law }\end{array}$ & $\begin{array}{l}\text { For the control of pollution emissions from } \\
\text { industries in specific areas }\end{array}$ \\
\hline 1989 & Environmental Protection Law (EPL) & $\begin{array}{l}\text { For the very first time, institutional buildings were } \\
\text { constructed for the enforcement of law }\end{array}$ \\
\hline 1998 & $\begin{array}{l}\text { Establishing acid rain and sulfur } \\
\text { dioxide }\left(\mathrm{SO}_{2}\right) \text { control areas }\end{array}$ & $\begin{array}{l}\text { Measures are developed to reduce the acid rain } \\
\text { and } \mathrm{SO}_{2} \text { pollutants in specific areas }\end{array}$ \\
\hline 2000 & $\begin{array}{l}\text { Amendment of Air Pollution } \\
\text { Prevention and Control Law }\end{array}$ & $\begin{array}{l}\text { Data related to air pollution was linked with } \mathrm{AQI} \\
\text { which was classified as natural, urban, and } \\
\text { industrial. Major pollutants were targeted i.e., } \mathrm{SO}_{2} \text {, } \\
\mathrm{NO}_{2} \text {, and } \mathrm{PM} \text { in } 42 \text { cities }\end{array}$ \\
\hline 2002 & $\begin{array}{l}\text { Environmental Impact Assessment } \\
\text { (EIA) law }\end{array}$ & $\begin{array}{l}\text { "Pollute first, clean up later" model was } \\
\text { developed to highlight the sources of pollution }\end{array}$ \\
\hline 2008 & $\begin{array}{l}\text { Ministry of Environmental Pollution } \\
(\mathrm{MEP})\end{array}$ & $\begin{array}{l}\text { State administration of Environmental Protection } \\
\text { was upgraded to a ministry }\end{array}$ \\
\hline 2010 & ODS $^{2}$ regulation & Control of ozone by ODS \\
\hline 2013 & $\begin{array}{l}\text { Air pollution prevention and control } \\
\text { action plan }\end{array}$ & $\begin{array}{l}\text { Its purpose was to reduce pollution in specific } \\
\text { regions. It aimed to reduce PM by } 10 \% \text { by } 2017 \text {. }\end{array}$ \\
\hline 2015 & Amendment of EPL & $\begin{array}{l}\text { According to these amendments, non-compliance } \\
\text { is punished with a high price, EIAs plans should } \\
\text { be made mandatory and public awareness } \\
\text { programs be done }\end{array}$ \\
\hline 2016 & $\begin{array}{l}\text { 2nd amendment in Air Pollution } \\
\text { Prevention and Control Law }\end{array}$ & $\begin{array}{l}\text { A system for co-operation between regions was } \\
\text { introduced. Limits of vehicle emissions were set } \\
\text { and involvement of local government } \\
\text { was enhanced }\end{array}$ \\
\hline 2016 & Amendment in EIA law & Increases the facilities and planning of EIA \\
\hline 2018 & Ministry of Ecology and Environment & The working structure of MEP is enhanced \\
\hline 2018 & Environmental Protection Tax law & To replace old pollution fee system \\
\hline 2018 & Blue sky war-winning action plan & $\begin{array}{l}\text { The second phase of the } 2013 \text { plan targets } \\
\text { reduction of VOCs, NOx, and ozone in more cities } \\
\text { in China }\end{array}$ \\
\hline
\end{tabular}

${ }^{1}$ AQI: Air Quality Index, ${ }^{2}$ ODS: Ozone-Depleting Substance.

Table 3. National Ambient Air Quality Standards (NAAQSs) of China [57].

\begin{tabular}{|c|c|c|c|c|c|c|c|c|c|}
\hline Year & No. of Standards & Grade $^{1}$ & $\mathrm{CO}^{2}$ & $\mathrm{NO}_{2}{ }^{3}$ & $\mathrm{SO}_{2}{ }^{3}$ & $\mathrm{O}_{3}^{4}$ & TSP $^{5}$ & $\mathrm{PM}_{2.5}{ }^{6}$ & $\mathrm{PM}_{10}{ }^{3}$ \\
\hline \multirow{3}{*}{1982} & \multirow{3}{*}{ GB3095-82 } & $\mathrm{I}$ & 100 & 50 & 50 & 120 & 150 & - & 50 \\
\hline & & II & 100 & 100 & 150 & 160 & 300 & - & 150 \\
\hline & & III & 200 & 150 & 250 & 200 & 500 & - & 250 \\
\hline \multirow{3}{*}{1996} & \multirow{3}{*}{ GB3095-1996 } & I & 100 & 40 & 20 & 120 & 80 & - & 40 \\
\hline & & II & 100 & 40 & 60 & 160 & 200 & - & 100 \\
\hline & & III & 200 & 80 & 100 & 200 & 300 & - & 150 \\
\hline \multirow{3}{*}{2000} & \multirow{3}{*}{ Amended GB3095-1996 } & I & 100 & 40 & 20 & 160 & 80 & - & 40 \\
\hline & & II & 100 & 80 & 60 & 200 & 200 & - & 100 \\
\hline & & III & 200 & 80 & 100 & 200 & 300 & - & 150 \\
\hline \multirow{2}{*}{2016} & \multirow{2}{*}{ GB3095-2012 } & I & 100 & 40 & 20 & 160 & 80 & 15 & 40 \\
\hline & & II & 100 & 40 & 60 & 200 & 200 & 35 & 70 \\
\hline
\end{tabular}

${ }^{1}$ Grade I: Places like forests and national parks, II: Rural, urban, industrial and commercial areas included, III: Heavy industry areas, ${ }^{2} \mathrm{CO}:$ $\mathrm{mg} / \mathrm{m}^{3}, 1 \mathrm{~h}$ average, ${ }^{3} \mathrm{NO}_{2}, \mathrm{SO}_{2}, \mathrm{PM}_{10}: \mu \mathrm{g} / \mathrm{m}^{3}, 24 \mathrm{~h}$ average, ${ }^{4} \mathrm{O}_{3} \mu \mathrm{g} / \mathrm{m}^{3}, 1 \mathrm{~h}$ average, ${ }^{5} \mathrm{TSP}$ : Total Suspended Particle, ${ }^{6} \mathrm{PM}_{2.5} \mu \mathrm{g} / \mathrm{m}^{3}$, 1-year average. 


\subsection{United Kingdom}

The Great Smog of London 1952, lessoned the people about the long term health consequences of air pollution. In 1956, Clean Air Act was introduced in England to cope with air pollution [58]. Smokeless burning facilities were announced in heavily polluted cities. Reforestation and the use of eco-friendly fuels are encouraged to reduce air pollution [59]. Despite efforts Ashford (109), Crowborough (108), Faversham (107), Ealing (106), London (104), Shenley (104), Cambridge (103), East Ham (103), Cranbrook (102), and Lewes (102) are most polluted cities of England [60]. United Kingdom followed the European Union laws and standards regarding air pollution as shown in Tables 4 and 5 .

Table 4. Evolution of European Union legislation on air pollution [61,62].

\begin{tabular}{|c|c|c|}
\hline Year & Law of Action & Description \\
\hline 1979 & $\begin{array}{l}\text { Convention on Long-range } \\
\text { Transboundary Air Pollution }\end{array}$ & $\begin{array}{l}\text { Focused mainly on pollutants that cause } \\
\text { eutrophication and acidification i.e., } \mathrm{NOx}, \\
\text { cadmium }(\mathrm{Cd}) \text {, lead }(\mathrm{Pb}) \text {, mercury }(\mathrm{Hg}), \mathrm{NH}_{3} \text {, } \\
\mathrm{PM}, \mathrm{SO}_{2} \text {, and VOCs }{ }^{1} \text {. }\end{array}$ \\
\hline 1980 & Directive 80/779/EEC ${ }^{2}$ & $\begin{array}{l}\text { This directive dictates the limitation levels of } \\
\mathrm{SO}_{2} \text { and } \mathrm{PM}\end{array}$ \\
\hline 1982 & Directive 82/884/EEC & Lead limitations were set \\
\hline 1985 & Directive 85/203/EEC & $\begin{array}{l}\text { This directive highlighted the } \mathrm{NO}_{2} \text { limitation } \\
\text { levels. It did not apply to the inside buildings }\end{array}$ \\
\hline 1988 & Directive 88/609/EEC & $\begin{array}{l}\text { The purpose of this Council directive was to } \\
\text { limit the emissions of certain pollutants i.e., } \mathrm{NOx} \\
\text { and } \mathrm{SO}_{2} \text { for large combustion plants. It helped } \\
\text { in the reduction of these pollutants. }\end{array}$ \\
\hline 1992 & Directive 92/72/EEC & $\begin{array}{l}\text { It introduced provisions related to tropospheric } \\
\mathrm{O}_{3} \text {. It holds the Environment Protection Agency } \\
\text { (EPA) responsible for measuring } \mathrm{O}_{3} \\
\text { concentrations and defining the threshold levels } \\
\text { of } \mathrm{O}_{3} \text { for industries. }\end{array}$ \\
\hline 1996 & Directive 96/61/EC & $\begin{array}{l}\text { It's a directive on Ambient Air Quality } \\
\text { Assessment and Management which aims at } \\
\text { preventing the harmful effects of pollutants on } \\
\text { the environment as well as human health. As } \\
\text { this directive failed four daughter directives } \\
\text { with more specificity were introduced }\end{array}$ \\
\hline 1999 & $\begin{array}{l}\text { 1st daughter directive } \\
\text { 1999/30/EC }\end{array}$ & $\begin{array}{l}\text { It focused on the limit levels of } \mathrm{NO}, \mathrm{NO}_{2}, \mathrm{SO}_{2} \text {, } \\
\text { lead }(\mathrm{Pb}) \text {, and dust. It aimed to protect the } \\
\text { ecosystem, plants, and humans. }\end{array}$ \\
\hline 2000 & $\begin{array}{l}\text { 2nd daughter directive } \\
\text { 2000/69/EC }\end{array}$ & $\begin{array}{l}\text { It defined the benzene and } \mathrm{CO} \text { acceptable levels. } \\
\text { Aims at the protection of humans }\end{array}$ \\
\hline 2002 & $\begin{array}{l}\text { 3rd daughter directive } \\
2002 / 3 / \mathrm{EC}\end{array}$ & $\begin{array}{l}\text { Ozone levels in ambient air. Aims at the } \\
\text { long-term protection of plants and humans. }\end{array}$ \\
\hline 2004 & $\begin{array}{l}\text { 4th daughter directive } \\
\text { 2004/107/EC }\end{array}$ & $\begin{array}{l}\text { It defined the acceptable levels of nickel, } \\
\text { cadmium, arsenic, and PAHs }{ }^{3} \text {. Aims to } \\
\text { protect humans. }\end{array}$ \\
\hline 2008 & Directive 2008/50/EC & $\begin{array}{l}\text { It's a directive on ambient air quality and cleaner } \\
\text { air for Europe. It replaced the directives from } \\
1996 \text { to } 2002 \text {. It ensures the enforcement of laws } \\
\text { regarding air pollution. It urges regional } \\
\text { authorities to take measures according to their } \\
\text { environmental conditions. If any region } \\
\text { surpasses the threshold level of pollutants, this } \\
\text { directive provides a deadline for reducing the } \\
\text { pollutant levels to the threshold. }\end{array}$ \\
\hline
\end{tabular}

${ }^{1}$ VOCs: Volatile organic compounds, ${ }^{2}$ EEC: European Environment Agency, ${ }^{3}$ PAHs: Polycyclic aromatic hydrocarbons. 
Table 5. Ambient Air Quality Standards of European Union [63].

\begin{tabular}{|c|c|c|c|}
\hline Pollutants & Average Time & Concentration & $\begin{array}{c}\text { Exceed Permitted } \\
\text { Each Year }\end{array}$ \\
\hline Carbon monoxide (CO) & $8 \mathrm{~h}$ & $10 \mathrm{mg} / \mathrm{m}^{3}$ & - \\
\hline Ozone $\left(\mathrm{O}_{3}\right)$ & $8 \mathrm{~h}$ & $120 \mu \mathrm{g} / \mathrm{m}^{3}$ & $\begin{array}{c}\text { Average of } 25 \text { days in } \\
3 \text { years }\end{array}$ \\
\hline Sulfur dioxide $\left(\mathrm{SO}_{2}\right)$ & $\begin{array}{c}1 \mathrm{~h} \\
24 \mathrm{~h}\end{array}$ & $\begin{array}{l}350 \mu \mathrm{g} / \mathrm{m}^{3} \\
125 \mu \mathrm{g} / \mathrm{m}^{3}\end{array}$ & $\begin{array}{c}24 \\
3\end{array}$ \\
\hline Lead $(\mathrm{Pb})$ & 1 year & $0.5 \mu \mathrm{g} / \mathrm{m}^{3}$ & - \\
\hline \multirow[t]{2}{*}{ Nitrogen dioxide $\left(\mathrm{NO}_{2}\right)$} & $1 \mathrm{~h}$ & $200 \mu \mathrm{g} / \mathrm{m}^{3}$ & 18 \\
\hline & 1 year & $40 \mu \mathrm{g} / \mathrm{m}^{3}$ & - \\
\hline $\mathrm{PM}_{2.5}$ & 1 year & $25 \mu \mathrm{g} / \mathrm{m}^{3}$ & - \\
\hline \multirow[t]{2}{*}{$\mathrm{PM}_{10}$} & $24 \mathrm{~h}$ & $50 \mu \mathrm{g} / \mathrm{m}^{3}$ & 35 \\
\hline & 1 year & $40 \mu \mathrm{g} / \mathrm{m}^{3}$ & - \\
\hline Arsenic (As) & 1 year & $6 \mathrm{ng} / \mathrm{m}^{3}$ & - \\
\hline Benzene & 1 year & $5 \mu \mathrm{g} / \mathrm{m}^{3}$ & - \\
\hline Nickel (Ni) & 1 year & $20 \mathrm{ng} / \mathrm{m}^{3}$ & - \\
\hline
\end{tabular}

\subsection{The USA}

Everybody has noticed the effects of the horrible brown haze in urban communities like Shanghai, China, or New Delhi, India. However, it is observed that there are issues with air contamination in the USA as well, particularly on the off chance that you live in California, as per the American Lung Association's 2018. California's Bay area encounters undeniable degrees of both smog and particulate matter contamination. In the colder time of year, wood smoke from chimneys causes significant degrees of smog [64]. In the USA, North fork (186), Oakhurst (186), Kamiah (184), Orofino (170) Hamilton (164), Moscow (162), McCall (160), La Jolla Shores (158), Lewiston (158), and Pullman (158) are worst cities in context to air pollution [65]. Other than these, Krasnoyarsk-Russia (169), Lima-Peru (163), Kabul-Afghanistan (156), Jakarta-Indonesia (152), Santiago-Chile (152), Tehran-Iran (108), and London-United Kingdom (104) are the top polluted communities of the world according to live stats of Air quality and pollution city ranking of 2021 [66]. The US legislation related to air pollution control have evolved much and has set some standard values for pollutants as shown in Tables 6 and 7.

Table 6. Evolution of U.S. legislation on air pollution [67,68].

\begin{tabular}{|c|c|c|}
\hline Year & Law or Action & Description \\
\hline 1955 & Air Pollution Control Act & $\begin{array}{l}\text { In 1948, a } 5 \text { days event of smog in Donora, an industrial town, in } \\
\text { Pennsylvania prompted the passing of the first air quality act in } \\
\text { the U.S. In 1955, air pollution was declared a national problem } \\
\text { under Air Pollution Control Act and research on air pollution } \\
\text { was funded. }\end{array}$ \\
\hline 1963 & $\begin{array}{l}\text { Clean Air Act (CAA) sets Nationwide Air } \\
\text { Quality Standards }\end{array}$ & $\begin{array}{l}\text { Under this act, public education programs were carried out and } \\
\text { researches regarding control of air pollution were supported. } \\
\text { However, it has no intention of reducing the air pollutants }\end{array}$ \\
\hline 1965 & Motor Vehicle Air Pollution Control Act & $\begin{array}{l}\text { With some amendments in CAA, standards regarding automobile } \\
\text { emissions were laid down. }\end{array}$ \\
\hline 1967 & Air Quality Act (AQA) & $\begin{array}{l}\text { This act distributed the responsibilities to the regions to develop } \\
\text { and implement control measures against air pollution. However, } \\
\text { this wasn't effective }\end{array}$ \\
\hline 1970 & Clean Air Act Amendments of 1970 & $\begin{array}{l}\text { A new CAA was passed to control six pollutants i.e., } \mathrm{CO}_{2}, \mathrm{NO}_{2} \text {, } \\
\mathrm{CO}, \mathrm{O}_{3}, \mathrm{PM} \text {, and lead. It also provided flexibility to Motor Vehicle } \\
\text { Air Pollution Control Act. EPA }{ }^{1} \text { was established to make sure the } \\
\text { implementation of the act. }\end{array}$ \\
\hline 1977 & Clean Air Act Amendments of 1977 & $\begin{array}{l}\text { It is concerned with provisions for the Prevention of Significant } \\
\text { Deterioration (PSD) of air quality in areas fulfilling NAAQS }{ }^{2} \text { as } \\
\text { well as areas not attaining NAAQS. }\end{array}$ \\
\hline 1990 & Clean Air Act Amendments of 1990 & $\begin{array}{l}\text { These revisions expanded the limits and responsibilities of the } \\
\text { federal government. New amendments were made regarding } \\
\text { control of acid rains, air toxins, } \mathrm{O}_{3} \text { depletion, and ground levels of } \\
\mathrm{O}_{3} \text {. EPA was authorized more responsibilities to enforce air } \\
\text { control acts and reduce air pollutants }\end{array}$ \\
\hline
\end{tabular}

${ }^{1}$ EPA: Environment Protection Agency, ${ }^{2}$ NAAQS: National Ambient Air Quality Standards. 
Table 7. National Ambient Air Quality Standards (NAAQSs) of United States [69].

\begin{tabular}{|c|c|c|c|c|}
\hline Pollutants & Average Times & Primary Standards 1 & Secondary Standards ${ }^{2}$ & Exceed Permitted \\
\hline Carbon monoxide (CO) & $1 \mathrm{~h}$ & $8 \mathrm{ppm}$ & - & $<1$ per year \\
\hline Ozone $\left(\mathrm{O}_{3}\right)$ & $8 \mathrm{~h}$ & $0.070 \mathrm{ppm}$ & $0.070 \mathrm{ppm}$ & $\begin{array}{l}\text { 4th highest average } \\
\text { max } 8 \text { h concentration, } \\
\text { averaged over } 3 \text { years } \\
\text { 99th\% of max } 8 \mathrm{~h}\end{array}$ \\
\hline Sulfur dioxide $\left(\mathrm{SO}_{2}\right)$ & $1 \mathrm{~h}$ & $75 \mathrm{ppb}$ & - & $\begin{array}{l}\text { concentration, } \\
\text { averaged over } 3 \text { years }\end{array}$ \\
\hline & $3 \mathrm{~h}$ & - & $0.5 \mathrm{ppm}$ & $<1$ per year \\
\hline Lead $(\mathrm{Pb})$ & 3 months & $0.15 \mu \mathrm{g} / \mathrm{m}^{3}$ & $0.15 \mu \mathrm{g} / \mathrm{m}^{3}$ & - \\
\hline Nitrogen dioxide $\left(\mathrm{NO}_{2}\right)$ & $1 \mathrm{~h}$ & $100 \mathrm{ppb}$ & - & $\begin{array}{c}\text { 98th } \% \text { of } \max 8 \mathrm{~h} \\
\text { concentration, } \\
\text { averaged over } 3 \text { years }\end{array}$ \\
\hline \multirow{3}{*}{$\mathrm{PM}_{2.5}$} & 1 year & $53 \mathrm{ppb}$ & $53 \mathrm{ppb}$ & Annual mean \\
\hline & $24 \mathrm{~h}$ & $35 \mu \mathrm{g} / \mathrm{m}^{3}$ & $35 \mu \mathrm{g} / \mathrm{m}^{3}$ & Annual mean \\
\hline & 1 year & $12 \mu \mathrm{g} / \mathrm{m}^{3}$ & $15 \mu \mathrm{g} / \mathrm{m}^{3}$ & Annual mean \\
\hline $\mathrm{PM}_{10}$ & $24 \mathrm{~h}$ & $150 \mu \mathrm{g} / \mathrm{m}^{3}$ & $150 \mu \mathrm{g} / \mathrm{m}^{3}$ & $<1$ per year \\
\hline
\end{tabular}

${ }^{1}$ Primary standard: Covers human health and sensitive groups (asthma patients and children), ${ }^{2}$ Secondary standards: Protects human welfare (plants, buildings, and animals).

\section{COVID-19 Pandemic}

The 2019 novel COVID or the extreme intense respiratory condition COVID-19 (SARSCoV-2) for what it's worth presently called, the 2019 novel COVID for what it's worth presently called, has quickly spread globally [70]. According to the World Health Organization (WHO) and Center for Disease Control (CDC) around $222 \mathrm{M}$ instances of COVID-19 (Coronavirus) and $4.6 \mathrm{M}$ fatalities have occurred till the 8th of September 2021. Most affected populations of the world are the USA (41 M cases), India (33 M cases), Brazil (20.9 M cases), Russia (7 M cases), UK (7 M cases), France (6.8 M cases), Turkey (6.5 M cases), Argentina (5.2 M cases), Iran (5.1 M cases), Colombia (4.9 M cases) and so on 223 countries of the world are affected [71].

Coronavirus is an RNA virus (enveloped) having a diameter of $60 \mathrm{~nm}$ to $140 \mathrm{~nm}$. Spike-like projections are present on its surface due to which it has a crown-like structure when observed under the electron microscope that's why it's named Coronavirus [72]. Pneumonia-like infection was first observed in Wuhan, Hubei region, China in December 2019 in local workers of the Hunan seafood market. Initially, they faced intense acute respiratory distress syndrome (ARDS) and respiratory failure in critical stages [73]. January 7. 2020, marks the day when SARS-CoV-2 was isolated for the very first time from the throat swabs of the patient. After China, it gradually spread in Thailand, Japan, Korea, and the USA. All first cases reported (26 out of 29) had a travel history to China. The remaining 3 had a meet-up or are relatives of the other 26 patients. This study conducted by WHO members confirmed that the seafood market of China was the epidemiological source of COVID-19 [74]. Moreover, they also concluded that coronavirus spread through human-tohuman contact, and no intermediary live host is involved in transmission. Coronavirus infection spreads from symptomatic people through droplets produced from coughing or sneezing as well as asymptomatic people [75]. The disease can also be attained by rubbing your nose, eyes after touching virus-contaminated surfaces. The stool of patients also contains the virus that results in contamination in the water supply [76].

\section{Smog and Coronavirus}

The correlation between air pollution and COVID-19 has pros and cons. Studies have backed both the aspects that COVID-19 mortality rates are high in highly polluted regions while the lockdown during the pandemic may lower the air pollution rates and thus lower the infection rates. Previous studies have proved that smog is a risk factor for respiratory 
infections by carrying microorganisms to humans and distressing the body's immunity to make people more vulnerable to pathogens $[77,78]$.

Smog effects on our health depend on several different factors, including the level of air pollutants, types of air pollutants, age and health conditions, exposure time, and where you live. Smog affects different organs of the body as shown in Figure 4 and Table 8. It can irritate our eyes, nose, and throat and can also cause existing heart and lung problems in people to worsen or lead to lung cancer if the exposure time of smog is long [3,79]. It also leads to premature death. Studies on ozone have shown that once it gets into your lungs, it can cause damage even when you are feeling well. It affects mainly those people who are at risk or suffer from heart and lung diseases. Children are most sensitive to smog because their respiratory systems are still underdeveloped and they have an active lifestyle [80]. However, these effects vary from person to person and exposure time. Healthy people who are exposed to smog for short period do not get long-term effects but in comparison, if a person is immunocompromised the effects will be long-term and might get worsen if the time of exposure is long and the dose is higher. Children are at more risk than adults, even if a low dose is present [81].

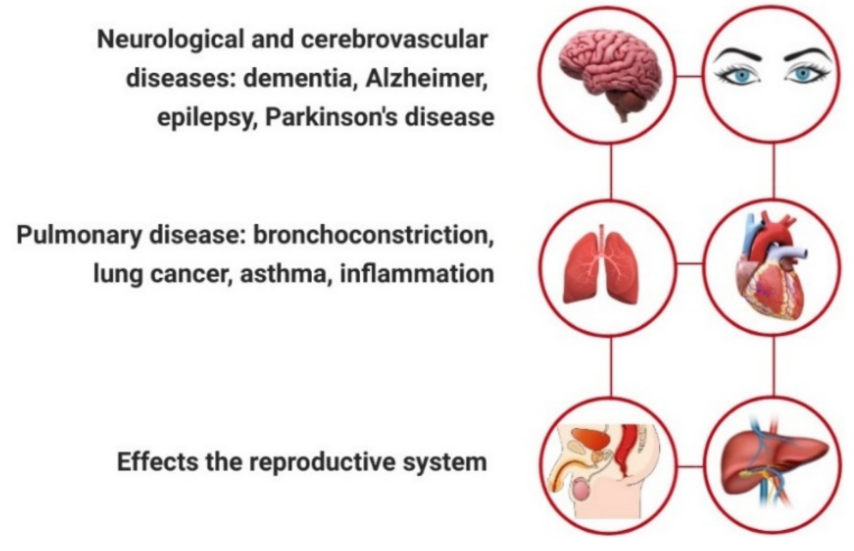

Irritation, burning and inflammation

of eyes, Subconjunctival disease

Cardiovascular diseases: Cardiac

arrhythmia, coronary artery disease,

ischemic chronic illness

Effects liver, spleen and blood

Figure 4. Effect of smog particles on different organs (nervous system, eyes, throat, lungs, heart, liver, spleen, and reproductive system) of the human body and the problems associated with it.

Table 8. Sources and diseases associated with sulfur dioxide, hydrocarbons, peroxyacetyl nitrate, nitrogen oxide, tropospheric ozone, and particulate matter i.e., different components of smog.

\begin{tabular}{|c|c|c|c|}
\hline $\begin{array}{c}\text { Smog } \\
\text { Components }\end{array}$ & Source & Effect & References \\
\hline Sulfur dioxide & $\begin{array}{l}\text { Industries, burning of fossil fuels, electric } \\
\text { generation plant, volcanic eruption }\end{array}$ & $\begin{array}{l}\text { Respiratory problems i.e., irritation, inflammation, } \\
\text { and infection. Asthma and reduced lung function. } \\
\text { Chronic obstructive pulmonary disease. } \\
\text { Cardiovascular disease, cardiac arrhythmias, } \\
\text { hemorrhagic stroke }\end{array}$ & [82-84] \\
\hline Hydrocarbons & Automobile exhaust and industries & Carcinogenic, may cause leukemia, lung cancer & [85] \\
\hline $\mathrm{PAN}^{1}$ & $\begin{array}{l}\text { Photochemical reaction of hydrocarbons and } \\
\text { nitrogen oxide }\end{array}$ & $\begin{array}{l}\text { Irritation in the eye. nose and throat, breathing } \\
\text { problems, damage to proteins }\end{array}$ & [86] \\
\hline Nitrogen oxide & $\begin{array}{l}\text { Combustion of fossil fuels, volcanic action, } \\
\text { lightning, forest fires }\end{array}$ & $\begin{array}{l}\text { Effects liver, spleen, and blood, kidney cancer, } \\
\text { prostate cancer, brain cancer, reduce the } \\
\text { birth length }\end{array}$ & [87] \\
\hline Tropospheric ozone & $\begin{array}{l}\text { Formed as a by-product of } \\
\text { photochemical smog }\end{array}$ & $\begin{array}{l}\text { Eye and respiratory irritation, cardiovascular } \\
\text { disease, heart failure, breast cancer, fatal bladder } \\
\text { cancer. Effects growth and bodyweight of the baby } \\
\text { throughout pregnancy. }\end{array}$ & [88-90] \\
\hline $\mathrm{PM}^{2}$ & Vehicles, industries & $\begin{array}{l}\text { Particles penetrate deep into the lungs, affect the } \\
\text { reproductive system, cause Parkinson's disease, } \\
\text { low birth weight, and halt fetal growth. }\end{array}$ & {$[91,92]$} \\
\hline
\end{tabular}

\footnotetext{
${ }^{1}$ PAN: peroxyacetyl nitrate, ${ }^{2}$ PM: Particulate matter.
} 
The pathogenesis of SARS-CoV-2 is similar to its closely related SARS-CoV-1 with an exception of the S-protein of SAR-CoV-2 that has a more binding affinity for Angiotensin Converting Enzyme-2 (ACE-2) receptors. Excess of plasma angiotensin-II is accumulated because of down-regulation of ACE2 leading to ARDS and myocarditis making other organs like the esophagus, kidney, lungs, heart, and ileum more vulnerable to SARS-CoV-2 [93]. Children under 5 years have low numbers of ACE2 receptors which probably makes them less susceptible to the disease [94].

The symptoms of the coronavirus vary from asymptomatic to severe respiratory diseases and organ damage. Some common symptoms include fever, fatigue, cough, headache, loss of smell and taste. Some people also suffer from acute lung injury (ALI) and impairment in blood clotting. Despite pulmonary damage being the cause of fatality, elderly patients also develop coronary heart diseases, atherosclerosis, ischemic cardiomyopathy, or hypertension. Apart from pulmonary damage COVID-19 is also involved in extrapulmonary disorders like lymphopenia (67-91\% of COVID-19 cases), proteinuria (87\%), hepatocellular injuries (14-53\%), gastrointestinal damage (12-61\%), thrombotic complications $(30 \%)$ and acute kidney injury (0.5-29\%) [95]. The death rate in elder people is more than that of young people [96]. The death rate of adult patients in hospitals ranges from $4-11 \%$, while the overall death rate is considered to range from $2-3 \%$.

\section{Amalgamation of Smog and COVID-19}

Since COVID-19 is a respiratory disease, it is investigated that smog results in the transmission of coronavirus, and SARS-CoV-2 can remain feasible in the air for hours [97]. Short-term exposure to elevated concentrations of air pollutants results in an increased risk of coronavirus infection. The significance of lessening air contamination is perceived under its notable effect on environmental change and its impact on wellbeing because of expanded bleakness and mortality related to smog and air pollution [98]. As per late investigations, smog appears to support the spread of coronavirus disease. As the viral particle is airborne, the impact of COVID-19 is exasperated by smog [99]. Even though there are opposing sentiments on the transmission of SARS-CoV-2, it appears that one can obtain the disease through the air [16] because of its strength in mist concentrates [97] and the reality that the pollutant cloud and its payload (microbe bearing droplets) can travel 7-8 m [100]. In a recent experiment, aerosols containing SARS-CoV-2 were created using three jet Collison nebulizers to mimic the aerosolized atmosphere. The viral load remained active for $3 \mathrm{~h}$ even though their virulent capacity was reduced [97]. Similarly, a double hit hypothesis has also been proposed initially in which $\mathrm{NO}_{2}$ and $\mathrm{PM}_{2.5}$ are considered responsible for coronavirus spread [19]. Particulate matter $\left(\mathrm{PM}_{2.5}\right)$ stabilizes the exhaled droplets in the air after fusing with them. The droplet would have evaporated rapidly in the atmosphere under normal air conditions but in high PM concentration, PM stabilizes the droplet and reduces its diffusion coefficient making it more transmissible. Moreover, a study conducted on mice supported the hypothesis that increased exposure to PM promoted the ACE2 and transmembrane-protease serine2 (TMPRSS2) production in macrophages and angiotensin-receptor type 2 (AT2) in lung tissues. This increase made the mice more susceptible to SARS-CoV-2 [101]. The studies conducted here supported the hypothesis that regions with a high concentration of air pollution are more affected by the coronavirus. Some of these studies are listed in Table 9.

From the above studies, it can be summarized that pollutants especially $\mathrm{NO}_{2}$ and $\mathrm{PM}$ are strongly responsible for respiratory disorders in humans. Similarly, SARS-CoV-2 is also associated with respiratory disorders. Therefore, the existence of air pollutants and coronavirus at a time can prove to be fatal as described in the earlier studies. 
Table 9. Studies correlating high COVID-19 incidences to the high rates of air pollution.

\begin{tabular}{|c|c|c|}
\hline Region & Study & References \\
\hline England & $\begin{array}{l}\text { This study suggested that people who have been } \\
\text { exposed to chronic levels of air pollution may have a } \\
\text { high instance of contracting severe COVID-19. This may } \\
\text { be attributed to the weakening of immune defense } \\
\text { protocol by air pollution. It has also been suggested that } \\
\text { mortality of COVID-19 may also be associated with } \\
\text { cytokine storm syndrome, a response of the immune } \\
\text { system that ascends to the chain of destructive events in } \\
\text { the body and eventually causes death. }\end{array}$ & [102] \\
\hline France & $\begin{array}{l}\text { A correlation between air pollution and COVID-19 } \\
\text { hospitalization maps has been studied. It was evident } \\
\text { that areas with high requirements of hospitalization due } \\
\text { to COVID-19 have also profound levels of } \mathrm{PM}_{2.5} \text {. }\end{array}$ & [103] \\
\hline Czech Republic & $\begin{array}{l}\text { In industrialized regions, high air pollution trends } \\
\text { correlate with COVID-19 hospitality. }\end{array}$ & [103] \\
\hline Poland & $\begin{array}{l}\text { Mazowieckie Voivodship, Upper Silesian Voivodship, } \\
\text { and Lower Silesian Voivodship hold a maximum } \\
\text { number of COVID-19 cases. All these regions have } \\
\mathrm{PM}_{2.5} \text { concentrations in the range } 19.58-29.84 \mu \mathrm{g} / \mathrm{m}^{3} \\
\text { which is higher than those set by WHO i.e., } 25 \mu \mathrm{g} / \mathrm{m}^{3} \text {. }\end{array}$ & [104] \\
\hline United States & $\begin{array}{l}\text { Just } 1 \mu \mathrm{g} / \mathrm{m}^{3} \text { increase in } \mathrm{PM}_{2.5} \text { concentration causes a } \\
15 \% \text { increase in COVID-19 fatality rates. }\end{array}$ & [105] \\
\hline United States & $\begin{array}{l}\text { The increase of } 4.6 \mathrm{ppb} \text { in a concentration of } \mathrm{NO}_{2} \\
\text { caused an increase in the mortality rate of COVID- } 19 \text { up } \\
\text { to } 16.2 \% \text {. If this } 4.6 \mathrm{ppb} \text { concentration could been } \\
\text { reduced it would have prevented } 14,000 \text { deaths of } \\
\text { COVID-19 patients. }\end{array}$ & [106] \\
\hline United Kingdom & $\begin{array}{l}\text { Out of the first } 44,000 \text { deaths of COVID-19, 6,100 (14\%) } \\
\text { deaths could be attributed to air pollution. }\end{array}$ & [107] \\
\hline Germany & $\begin{array}{l}\text { Long term exposure to air pollution is involved in } 26 \% \\
\text { of COVID-19 fatalities. }\end{array}$ & [108] \\
\hline Lima & $\begin{array}{l}\text { A higher concentration of } \mathrm{PM}_{2.5} \text { is responsible for the } \\
\text { increase in COVID-19 cases however it does not affect } \\
\text { the rate of COVID-19 fatalities. }\end{array}$ & [109] \\
\hline Italy & $\begin{array}{l}\text { Most COVID-19 affected regions had a high } \\
\text { concentration of } \mathrm{PM}_{2.5} \text { and } \mathrm{PM}_{10} \text { during February } 2020 .\end{array}$ & [110] \\
\hline
\end{tabular}

\section{Impact of Lockdown on Smog}

Since the 15th of December 2019, transmission from patients to medical care staff has happened, which shows that human-to-human transmission has occurred through close contact [111]. Most nations have forced city lockdown also, quarantine measures to diminish transmission to manage the epidemic. Public danger correspondence exercises have been performed to improve public attention to self-insurance [112]. The Chinese government has step by step executed a severe lockdown on Wuhan and encompassing urban areas as of 23 January 2020. Not before long, the Government of India also reported a total cross-country lockdown, from the 24th of March 2020. All industries, entertainment centers have been temporarily shut down. Domestic as well as all international flights have been suspended, trains and public transport have been temporarily banned [113].

The lockdowns imposed by governments all around the world have caused economical and financial instability. However, due to lockdowns $30 \%$ reduction in air pollutants have been evident in COVID-19 epicenters like Brazil, the USA, Spain, Italy, Wuhan according to reports of the Center for Research on Energy and Clean Air (CREA), European Space Agency (ESA), and National Aeronautics and Space Administration (NASA). NASA and ESA have reported a substantial drop of $2.5 \mu$ diameter in $\left(\mathrm{PM}_{2.5}\right.$ and $\left.\mathrm{PM}_{10}\right)$ in Beijing, China where most of the pollution comes from heating instruments in the winters and heavy industrialization [24]. During the time of lockdown, air quality and smog conditions would 
be predicted to have improved in favor of life being. Due to traffic and industrial lockdown, a fall of $\sim 63 \%$ in the concentration of $\mathrm{NO}_{2}$ is evident in Wuhan, China. This fall in $\mathrm{NO}_{2}$ concentration resulted in fewer deaths of people in Wuhan (496 deaths prevented), Hubei (3368 deaths prevented), and in China (10,822 deaths prevented). Similarly, a shortfall of $20 \mu \mathrm{g} / \mathrm{m}^{3}$ in $\mathrm{PM}_{10}$ concentration is also observed in Wuhan. However, no reduction was noticed in $\mathrm{SO}_{2}$ and $\mathrm{CO}$ concentration because of the dependence of the country on coal-based energy plants [114].

Another study conducted over Pakistan stated a decrease of $7.39 \%$ in $\mathrm{PM}_{2.5}$ and 4.13-5.78\% drop in column aerosol optical thickness (AOT) [115]. Hernandez-Paniagua and his colleagues concluded that due to the lockdown of motor vehicles, the concentration of $\mathrm{NO}_{2}$ and $\mathrm{PM}_{2.5}$ decrease significantly in Mexico. However, other pollutants concentration remains almost undisturbed except for an increase in $\mathrm{O}_{3}$ concentration [116]. In Ontario, Canada $\mathrm{NO}$ and $\mathrm{NO}_{2}$ concentration decreased rapidly while $\mathrm{O}_{3}$ concentration decreased slowly but $\mathrm{PM}_{2.5}$ remained the same [117]. Madrid, Spain faced a downfall in $\mathrm{NO}_{2}$ concentration by $62 \%$ [118]. In Gujarat, India 30-84\% reduction in $\mathrm{NO}_{2}$ occurred while $\mathrm{O}_{3}$ increased by $16-58 \%$ [119]. The atmosphere of Delhi, India got rid of $55 \%$ of $\mathrm{PM}_{10}, 49 \%$ of $\mathrm{PM}_{2.5}, 60 \%$ of $\mathrm{NO}_{2}$, and $19 \%$ of $\mathrm{SO}_{2}$ while Mumbai, India got rid of $44 \%$ of $\mathrm{PM}_{10}, 37 \%$ of $\mathrm{PM}_{2.5}, 78 \%$ of $\mathrm{NO}_{2}$ and $39 \%$ of $\mathrm{SO}_{2}$ [120]. Some figures before and after lockdown are listed in Table 10.

Table 10. Relative percentage difference of pollutants before and during the lockdown in different regions of the world [115].

\begin{tabular}{ccccc}
\hline Pollutants & Region & $\begin{array}{c}\text { Before } \\
\text { Lockdown }\end{array}$ & $\begin{array}{c}\text { During } \\
\text { Lockdown }\end{array}$ & $\begin{array}{c}\text { Relative } \\
\text { Percentage } \\
\text { Difference (\%) }\end{array}$ \\
\hline $\mathrm{SO}_{2}\left(\mu \mathrm{g} / \mathrm{m}^{3}\right)$ & Hubei (China) & 15.81 & 13.83 & -13.36 \\
$\mathrm{SO}_{2}(\mathrm{DU})^{1}$ & Malaysia & 1.42 & 0.99 & -35.68 \\
& Sale (Morocco) & 6.6 & 3.3 & -0.49 \\
& Chennai (India) & 44.1 & 45.2 & -2.46 \\
$\mathrm{CO}(\mathrm{ppbv})^{2}$ & Delhi (India) & 1.03 & 0.72 & -30.35 \\
& Hubei (China) & 1.207 & 1.02 & -16.79 \\
& Kolkata (India) & 0.6 & 0.5 & -18.18 \\
& Malaysia & 0.8 & 0.49 & -48.06 \\
& Chennai (India) & 29.38 & 27.33 & -7.23 \\
& Delhi (India\}) & 80.51 & 37.75 & -53.11 \\
& Hubei (China) & 81.83 & 65.81 & -21.70 \\
& Malaysia & 32.3 & 22.34 & -36.46 \\
& Sao Paulo & 12.9 & 12.5 & -3.6 \\
& (Brazil) & 65.5 & 40.11 & -48.08 \\
\hline
\end{tabular}

${ }^{1}$ DU: Dosbin Unit, ppbv: ${ }^{2}$ Parts per billion by volume

After the lockdown of city traffic, workforce stream control turned into the main perspective. Traffic contamination produces $\mathrm{NO}, \mathrm{NO}_{2}, \mathrm{CO}, \mathrm{CO}_{2}$, hydrocarbons, and toxins that are injurious to health [121]. There was a distinguishable relationship between traffic-associated air contamination and early mortality, and the danger of respiratory and cardiovascular diseases enlarged in people living close to elevated traffic polluted places [122]. Decreasing the outflows from engine vehicles, particularly trucks and transports, could deliver extensive medical advantages [123]. After lockdown, many surveys were done in hospitals which showed that after a consecutive lockdown of 14 days there was seen a major decline in children in hospitals complaining of asthma problems [124]. In accretion, the decrease in industrial actions after the lockdown also forces definite environmental and health effects. The lockdown has caused financial downfalls in many countries and cities, but it also has given clean air to residents of some of the world's most contaminated cities. The coronavirus pandemic has led to the decrease in the concentration of 
pollutants like $\mathrm{SO}_{2}, \mathrm{NO}_{2}, \mathrm{CO}, \mathrm{PM}_{2.5}$ that contribute to smog all over the world and to some extend have enhanced the air quality in most of the polluted cities of the world $[125,126]$.

\section{Limitations of the Study}

This is a narrative literature review that provides a simple insight into the relation between air pollution and coronavirus in large representative populations. The key limitation of this review is that the individual-level risk factors like race, age, and smoking status are not included. Moreover, chances of miscalculation are always there because during the study we assumed that all people in the region are exposed to equal concentrations of air pollution. The relation between smog and COVID-19 is based on area-level studies so the data is useful to develop coping strategies against the situation in a specific area.

\section{Conclusions}

Human activities like the burning of fossil fuels, coal combustion, and the smoke from exhausts of automobiles release toxic gases which react in the atmosphere and give rise to secondary pollutants. All these pollutants collectively contribute to smog. Each year rise in respiratory disease is related to smog episodes. Moreover, cardiovascular diseases, neurological disorders, underdevelopment of fetuses, and cancer are the major diseases that are related to smog pollution. Smog episodes can have deleterious effects amidst the COVID-19 pandemic. When a person is long exposed to air pollution, the coronavirus would have an additive effect on the respiratory and cardiovascular systems of the human. From the studies conducted it seems that particulate matter and nitrogen oxides increase the activity and production of ACE2 which in turn enhances the chances of uptake of SARS-CoV-2 and could damage lungs, heart, and blood vessels. However, the relation between smog and coronavirus isn't this. They share an ambiguous relation where on the one hand air pollution may worsen the COVID-19 mortality rate, the lockdown imposed because of a pandemic may have some positive aspects as well. During the lockdown periods, a significant decrease in some of the pollutants like $\mathrm{NO}_{2}, \mathrm{SO}_{2}$, and $\mathrm{PM}$ have been recorded. For a better future, anthropogenic emissions need to be controlled because vaccines are effective against pandemics and not against air pollution.

Author Contributions: Writing-review and editing, A.J. and F.A.; visualization, A.J. and F.A.; supervision, U.F.G. and R.A.M.; project administration, H.M.; investigation, M.Z.-U.-H. and M.O.A.; formal analysis, M.N.B.-J. and O.L.P. All authors have read and agreed to the published version of the manuscript.

Funding: This research was partially funded by UEFISCDI, grant number PN-III-P4-IDPCE-20202126 and FDI-0013.

Institutional Review Board Statement: Not applicable.

Informed Consent Statement: Not applicable.

Data Availability Statement: No new data were created or analyzed in this study. Data sharing does not apply to this article.

Acknowledgments: We thank the Institute of Industrial Biotechnology, Government College University Lahore, Pakistan for providing moral and technical support.

Conflicts of Interest: The authors declare no conflict of interest.

\section{References}

1. Ali, Y.; Razi, M.; De Felice, F.; Sabir, M.; Petrillo, A. A VIKOR based approach for assessing the social, environmental and economic effects of "smog" on human health. Sci. Total Environ. 2019, 650, 2897-2905. [CrossRef]

2. Laskin, D. The Great London Smog. Weatherwise 2006, 59, 42-45. [CrossRef]

3. Shah, A.S.V.; Langrish, J.P.; Nair, H.; McAllister, D.A.; Hunter, A.L.; Donaldson, K.; Newby, D.E.; Mills, N.L. Global association of air pollution and heart failure: A systematic review and meta-analysis. Lancet 2013, 382, 1039-1048. [CrossRef]

4. Ashraf, A.; Butt, A.; Khalid, I.; Alam, R.U.; Ahmad, S.R. Smog analysis and its effect on reported ocular surface diseases: A case study of 2016 smog event of Lahore. Atmos. Environ. 2019, 198, 257-264. [CrossRef] 
5. Hidy, G.M. An historical experiment: Los Angeles smog evolution observed by blimp. J. Air Waste Manag. Assoc. 2018, 68, 643-655. [CrossRef]

6. Roman, M.; Idrees, M.; Ullah, S.; Idrees, M.; Sharif, M.; Street, P.; District, H. A Sociological Study of Environmental Pollution and Its Effects on the Public Health Faisalabad City. Int. J. Educ. Res. 2013, 1, 1-12.

7. Soto-Coloballes, N. The Development of Air Pollution in Mexico City. SAGE Open 2020, 10, 2158244020931072. [CrossRef]

8. Tang, D. A Comparison of Control Methods of Air Pollution in London and Beijing. Int. J. Environ. Sci. Dev. 2019, 10, 141-150. [CrossRef]

9. Yadav, S.; Rawal, G. The great Delhi smog. Indian J. Immunol. Respir. Med. 2016, 1, 78-79.

10. Mishra, S. Is smog innocuous? Air pollution and cardiovascular disease. Indian Heart J. 2017, 69, 425-429. [CrossRef]

11. Stafoggia, M.; Schwartz, J.; Forastiere, F.; Perucci, C.A. Does temperature modify the association between air pollution and mortality? A multicity case-crossover analysis in Italy. Am. J. Epidemiol. 2008, 167, 1476-1485. [CrossRef]

12. Yang, H.; Li, S.; Sun, L.; Zhang, X.; Cao, Z.; Xu, C.; Cao, X.; Cheng, Y.; Yan, T.; Liu, T.; et al. Smog and risk of overall and type-specific cardiovascular diseases: A pooled analysis of 53 cohort studies with 21.09 million participants. Environ. Res. 2019, 172, 375-383. [CrossRef]

13. Altindag, D.T.; Baek, D.; Mocan, N. Chinese Yellow Dust and Korean infant health. Soc. Sci. Med. 2017, 186, 78-86. [CrossRef]

14. Maher, A.; Abdel Rahman, M.F.; Gad, M.Z. The role of nitric oxide from neurological disease to cancer. Adv. Exp. Med. Biol. 2017, 1007, 71-88. [CrossRef]

15. Ontawong, A.; Saokaew, S.; Jamroendararasame, B.; Duangjai, A. Impact of long-term exposure wildfire smog on respiratory health outcomes. Expert Rev. Respir. Med. 2020, 14, 527-531. [CrossRef]

16. Cao, Y.; Chen, M.; Dong, D.; Xie, S.; Liu, M. Environmental pollutants damage airway epithelial cell cilia: Implications for the prevention of obstructive lung diseases. Thorac. Cancer 2020, 11, 505-510. [CrossRef]

17. Tsai, D.H.; Riediker, M.; Berchet, A.; Paccaud, F.; Waeber, G.; Vollenweider, P.; Bochud, M. Effects of short- and long-term exposures to particulate matter on inflammatory marker levels in the general population. Environ. Sci. Pollut. Res. 2019, 26, 19697-19704. [CrossRef]

18. Conticini, E.; Frediani, B.; Caro, D. Can atmospheric pollution be considered a co-factor in extremely high level of SARS-CoV-2 lethality in Northern Italy? Environ. Pollut. 2020, 261, 114465. [CrossRef]

19. Paital, B.; Kumar, P. Air pollution by $\mathrm{NO}_{2}$ and $\mathrm{PM}_{2.5}$ explains COVID-19 infection severity by overexpression of angiotensinconverting enzyme 2 in respiratory cells: A review. Environ. Chem. Lett. 2021, 19, 25-42. [CrossRef]

20. Mele, M.; Magazzino, C.; Schneider, N.; Strezov, V. $\mathrm{NO}_{2}$ levels as a contributing factor to COVID-19 deaths: The first empirical estimate of threshold values. Environ. Res. 2021, 194, 110663. [CrossRef]

21. Filippini, T.; Rothman, K.J.; Cocchio, S.; Narne, E.; Mantoan, D.; Saia, M.; Goffi, A.; Ferrari, F.; Maffeis, G.; Orsini, N. Associations between mortality from COVID-19 in two Italian regions and outdoor air pollution as assessed through tropospheric nitrogen dioxide. Sci. Total Environ. 2021, 760, 143355.

22. Leung, W.W.F.; Sun, Q. Electrostatic charged nanofiber filter for filtering airborne novel coronavirus (COVID-19) and nanoaerosols. Sep. Purif. Technol. 2020, 250, 116886. [CrossRef]

23. Domingo, J.L.; Rovira, J. Effects of air pollutants on the transmission and severity of respiratory viral infections. Environ. Res. 2020, 187, 109650. [CrossRef]

24. Dutheil, F.; Navel, V.; Clinchamps, M. The Indirect Benefit on Respiratory Health From the World's Effort to Reduce Transmission of SARS-CoV-2. Chest 2020, 158, 467-468. [CrossRef] [PubMed]

25. Nemery, B.; Hoet, P.H.M.; Nemmar, A. Department of medical history The Meuse Valley fog of 1930: An air pollution disaster. Lancet 2001, 357, 704-708. [CrossRef]

26. Firket, J. Fog along the Meuse valley. Cornell Univ. Libr. 1978, 68, 1421-1448. [CrossRef]

27. Tim, B.Y.; St, O.N. 28 November 1939: The Day "Black Tuesday" Rolled into St. Louis. Available online: https: / / www.stltoday.com/news/local/history/nov-28-1939-the-day-black-tuesday-rolled-into-st-louis/article_00c3b6cd-ba695a19-b498-fbc29f9630c4.html (accessed on 20 October 2021).

28. Johnson, H.R.; Johnson, H.R. PM 2.5 Pollution and Temperature Inversions: A Case Study in St. Louis, MO; Iowa State University: Ames, IA, USA, 2018.

29. Tucker-, R.R. Smoke prevention in St. Louis. Ind. Eng. Chem. 1941, 33, 836-839. [CrossRef]

30. Hoffman, D.G. Three Ballads of the Donora Smog. N. Y. Folkl. Q. 1949, 5, 51.

31. Helfand, W.H.; Lazarus, J.; Theerman, P. Donora, Pennsylvania: An environmental disaster of the 20th century. Am. J. Public Health 2001, 91, 553. [CrossRef]

32. Jacobs, E.T.; Burgess, J.L.; Abbott, M.B. The Donora Smog Revisited: 70 Years After the Event That Inspired the Clean Air Act. Am. J. Public Health 2018, 108, S85-S88. [CrossRef]

33. Ball, A. Air pollution, foetal mortality, and long-term health: Evidence from the Great London Smog. Munich Pers. RePEc Arch. Eurpean Univ. Inst. 2015.

34. Polivka, B.J. The Great London Smog of 1952. Am. J. Nurs. 2018, 118, 57-61. [CrossRef]

35. Bell, M.L.; Davis, D.L. Reassessment of the lethal London fog of 1952: Novel indicators of acute and chronic consequences of acute exposure to air pollution. Environ. Health Perspect. 2001, 109, 389-394. [CrossRef] 
36. Czerwińska, J.; Wielgosiński, G. The effect of selected meteorological factors on the process of "Polish smog" formation. J. Ecol. Eng. 2020, 21, 180-187. [CrossRef]

37. Czerwińska, J.; Wielgosiński, G.; Szymańska, O. Is the Polish Smog a New Type of Smog? Ecol. Chem. Eng. S 2019, 26, 465-474. [CrossRef]

38. Loyola, D.; Van Geffen, J.; Valks, P.; Erbertseder, T.; Van Roozendael, M.; Thomas, W.; Zimmer, W.; Wißkirchen, K. Satellite-based detection of volcanic sulphur dioxide from recent eruptions in Central and South America. Adv. Geosci. 2008, 14, 35-40. [CrossRef]

39. Vecchiato, M.; Bonato, T.; Bertin, A.; Argiriadis, E.; Barbante, C.; Piazza, R. Plant Residues as Direct and Indirect Sources of Hydrocarbons in Soils: Current Issues and Legal Implications. Environ. Sci. Technol. Lett. 2017, 4, 512-517. [CrossRef]

40. Dewulf, J.; Langenhove, H. Van Hydrocarbons in the atmosphere. In Environmental and Ecological Chemistry; Encyclopedia of Life Support Systems (EOLSS); Unesco: Paris, France, 2000; Volume 2.

41. Hallquist, M.; Munthe, J.; Hu, M.; Wang, T.; Chan, C.K.; Gao, J.; Boman, J.; Guo, S.; Hallquist, A.M.; Mellqvist, J.; et al. Photochemical smog in China: Scientific challenges and implications for air-quality policies. Natl. Sci. Rev. 2016, 3, 401-403. [CrossRef]

42. Li, B.; Shi, H.; Yang, D.C.; Peng, M. Smog Pollution, Environmental Uncertainty, and Operating Investment. Atmosphere 2021, 12, 1378. [CrossRef]

43. Tofte, K.; Chu, P.S.; Barnes, G.M. Large-scale weather patterns favorable for volcanic smog occurrences on O'ahu, Hawai'i. Air Qual. Atmos. Health 2017, 10, 1163-1180. [CrossRef]

44. Wang, H.; Wang, Q.; Gao, Y.; Zhou, M.; Jing, S.; Qiao, L.; Yuan, B.; Huang, D.; Huang, C.; Lou, S.; et al. Estimation of Secondary Organic Aerosol Formation During a Photochemical Smog Episode in Shanghai, China. J. Geophys. Res. Atmos. 2020, 125, 1-14. [CrossRef]

45. Yin, S.; Zhang, X.; Yu, A.; Sun, N.; Lyu, J.; Zhu, P.; Liu, C. Determining $\mathrm{PM}_{2.5}$ dry deposition velocity on plant leaves: An indirect experimental method. Urban For. Urban Green. 2019, 46, 126467. [CrossRef]

46. Carmona-Cabezas, R.; Gómez-Gómeiaz, J.; Gutiérrez de Ravé, E.; Jiménez-Hornero, F.J. Checking complex networks indicators in search of singular episodes of the photochemical smog. Chemosphere 2020, 241, 125085. [CrossRef]

47. Read, C.; Parton, K.A. The impact of the 1952 London smog event and its relevance for current wood-smoke abatement strategies in Australia. J. Air Waste Manag. Assoc. 2019, 69, 1049-1058. [CrossRef] [PubMed]

48. Burchard-Dziubińska, M. Air pollution and health in Poland: Anti-smog movement in the most polluted Polish cities. Ekon. Sr. 2019, 2, 76-90. [CrossRef]

49. Raza, W.; Saeed, S.; Saulat, H.; Gul, H.; Sarfraz, M.; Sonne, C.; Kim, K.-H. A review on the deteriorating situation of smog and its preventive measures in Pakistan. J. Clean. Prod. 2021, 279, 123676. [CrossRef]

50. Yu, X.; Shen, M.; Shen, W.; Zhang, X. Effects of land urbanization on smog pollution in China: Estimation of spatial autoregressive panel data models. Land 2020, 9, 337. [CrossRef]

51. Air Pollution Linked to 1.2 Million Deaths in China-The New York Times. Available online: https://www.nytimes.com/2013/0 4/02/world/asia/air-pollution-linked-to-1-2-million-deaths-in-china.html (accessed on 13 July 2021).

52. Xu, Q.; Li, X.; Wang, S.; Wang, C.; Huang, F.; Gao, Q.; Wu, L.; Tao, L.; Guo, J.; Wang, W. Fine particulate air pollution and hospital emergency room visits for respiratory disease in urban areas in Beijing, China, in 2013. PLoS ONE 2016, 11, e0153099. [CrossRef]

53. Zhou, M.; He, G.; Fan, M.; Wang, Z.; Liu, Y.; Ma, J.; Ma, Z.; Liu, J.; Liu, Y.; Wang, L.; et al. Smog episodes, fine particulate pollution and mortality in China. Environ. Res. 2015, 136, 396-404. [CrossRef] [PubMed]

54. China Air Quality Index (AQI) and Air Pollution information I AirVisual. Available online: https://www.iqair.com/us/china (accessed on 13 July 2021).

55. Maji, K.J.; Li, V.O.K.; Lam, J.C.K. Effects of China's current Air Pollution Prevention and Control Action Plan on air pollution patterns, health risks and mortalities in Beijing 2014-2018. Chemosphere 2020, 260, 127572. [CrossRef] [PubMed]

56. Yang, C. Policies, reglatory framework and enforcement for air quality management: The case of China-Environment working paper no.157. Organ. Econ. Co-operation Dev. 2020, 4.

57. Li, Y.; Tang, Y.; Fan, Z.; Zhou, H.; Yang, Z. Assessment and comparison of three different air quality indices in China. Environ. Eng. Res. 2018, 23, 21-27. [CrossRef]

58. Longhurst, J.W.S.; Barnes, J.H.; Chatterton, T.J.; Hayes, E.T.; Williams, W.B. Progress with air quality management in the 60 years since the UK clean air act, 1956. Lessons, failures, challenges and opportunities. Int. J. Sustain. Dev. Plan. 2016, 11, 491-499. [CrossRef]

59. Burakowski, E.A.; Ollinger, S.V.; Bonan, G.B.; Wake, C.P.; Dibb, J.E.; Hollinger, D.Y. Evaluating the climate effects of reforestation in New England using a Weather Research and Forecasting (WRF) model multiphysics ensemble. J. Clim. 2016, 29, 5141-5156. [CrossRef]

60. England Air Quality Index (AQI) and United Kingdom Air Pollution I AirVisual. Available online: https://www.iqair.com/uk/ england (accessed on 13 July 2021).

61. Crippa, M.; Janssens-Maenhout, G.; Dentener, F.; Guizzardi, D.; Sindelarova, K.; Muntean, M.; Van Dingenen, R.; Granier, C. Forty years of improvements in European air quality: Regional policy-industry interactions with global impacts. Atmos. Chem. Phys. 2016, 16, 3825-3841. [CrossRef]

62. Orlando, E. The evolution of EU policy and law in the environmental field: Achievements and current challenges. EU, US Glob. Clim. Gov. 2016, 61-80. 
63. EU: Air Quality Standards I Transport Policy. Available online: https://www.transportpolicy.net/standard/eu-air-qualitystandards / (accessed on 7 September 2021).

64. Air Pollution Facts, Causes and the Effects of Pollutants in the Air I NRDC. Available online: https://www.nrdc.org/stories/airpollution-everything-you-need-know (accessed on 13 July 2021).

65. USA Air Quality Index (AQI) and Air Pollution Information I AirVisual. Available online: https://www.iqair.com/usa (accessed on 13 July 2021).

66. World Air Quality Index (AQI) Ranking / AirVisual. Available online: https://www.iqair.com/world-air-quality-ranking (accessed on 13 July 2021).

67. Kuklinska, K.; Wolska, L.; Namiesnik, J. Air quality policy in the U.S. and the EU-A review. Atmos. Pollut. Res. 2015, 6, 129-137. [CrossRef]

68. Evolution of the Clean Air Act I US EPA. Available online: https:/ / www.epa.gov/clean-air-act-overview / evolution-clean-air-act (accessed on 7 September 2021).

69. NAAQS Table IUS EPA. Available online: https://www.epa.gov/criteria-air-pollutants/naaqs-table (accessed on 7 September 2021).

70. Wang, C.; Horby, P.W.; Hayden, F.G.; Gao, G.F. A novel coronavirus outbreak of global health concern. Lancet 2020, 395, 470-473. [CrossRef]

71. COVID Live Update: 222,812,592 Cases and 4,601,142 Deaths from the Coronavirus-Worldometer. Available online: https: //www.worldometers.info/coronavirus/\#countries (accessed on 7 September 2021).

72. Richman, D.; Whitely, R.; Hayden, F.G. Clinical Virology, 4th ed.; Wiley: Hoboken, NJ, USA, 2016.

73. Chen, N.; Zhou, M.; Dong, X.; Qu, J.; Gong, F.; Han, Y.; Qiu, Y.; Wang, J.; Liu, Y.; Wei, Y.; et al. Epidemiological and Clinical Characteristics of 99 Cases of 2019 Novel Coronavirus Pneumonia in Wuhan, China: A Descript. Lancet 2020, 395, 507-513. [CrossRef]

74. Muralidar, S.; Visaga, S.; Sekaran, S. The emergence of COVID-19 as a global pandemic: Understanding the epidemiology, immune response and potential therapeutic targets of SARS-CoV-2. Biochimie 2020, 179, 85-100.

75. Rothe, C.; Schunk, M.; Sothmann, P.; Bretzel, G.; Froeschl, G.; Wallrauch, C.; Zimmer, T.; Thiel, V.; Janke, C.; Guggemos, W.; et al. Transmission of 2019-nCoV Infection from an Asymptomatic Contact in Germany. N. Engl. J. Med. 2020, 382, 970-971. [CrossRef]

76. World Health Organization. Clinical Management of Severe Acute Respiratory Infection When Novel Coronavirus (2019-nCoV) Infection Is Suspected: Interim Guidance 28 January 2020; WHO: Geneva, Switzerland, 2020; p. 10.

77. Becker, S.; Soukup, J.M. Exposure to urban air particulates alters the macrophage-mediated inflammatory response to respiratory viral infection. J. Toxicol. Environ. Health-Part A 1999, 57, 445-457. [CrossRef]

78. Cai, Q.C.; Lu, J.; Xu, Q.F.; Guo, Q.; Xu, D.Z.; Sun, Q.W.; Yang, H.; Zhao, G.M.; Jiang, Q.W. Influence of meteorological factors and air pollution on the outbreak of severe acute respiratory syndrome. Public Health 2007, 121, 258-265. [CrossRef]

79. Valavanidis, A.; Vlachogianni, T.; Fiotakis, K.; Loridas, S. Pulmonary oxidative stress, inflammation and cancer: Respirable particulate matter, fibrous dusts and ozone as major causes of lung carcinogenesis through reactive oxygen species mechanisms. Int. J. Environ. Res. Public Health 2013, 10, 3886-3907. [CrossRef] [PubMed]

80. Coneus, K.; Spiess, C.K. Pollution exposure and child health: Evidence for infants and toddlers in Germany. J. Health Econ. 2012, 31, 180-196. [CrossRef]

81. Gehring, U.; Wijga, A.H.; Hoek, G.; Bellander, T.; Berdel, D.; Brüske, I.; Fuertes, E.; Gruzieva, O.; Heinrich, J.; Hoffmann, B.; et al. Exposure to air pollution and development of asthma and rhinoconjunctivitis throughout childhood and adolescence: A population-based birth cohort study. Lancet Respir. Med. 2015, 3, 933-942. [CrossRef]

82. Camara, J.G.; Lagunzad, J.K.D. Ocular findings in volcanic fog induced conjunctivitis. Hawaii Med. J. 2011, 70, $262-265$.

83. Longo, B.M. Adverse Health Effects Associated with Increased Activity at Killauea Volcano: A Repeated Population-Based Survey. ISRN Public Health 2013, 2013, 475962. [CrossRef]

84. Williams-Jones, G.; Rymer, H. Hazards of Volcanic Gases, 2nd ed.; Elsevier Inc.: Amsterdam, The Netherlands, 2015; ISBN 9780123859389.

85. Folabi, T.; Phan, T. Evaluation of Volatile Organic Compounds and Polyaromatic Hydrocarbons in Barker Reservoir in Houston, Texas after the 2017 Hurricane Harvey. Am. J. Anal. Chem. 2020, 11, 376-388. [CrossRef]

86. Zhang, B.; Zhao, B.; Zuo, P.; Huang, Z.; Zhang, J. Influencing factors and prediction of ambient Peroxyacetyl nitrate concentration in Beijing, China. J. Environ. Sci. 2019, 77, 189-197. [CrossRef] [PubMed]

87. Munawer, M.E. Human health and environmental impacts of coal combustion and post-combustion wastes. J. Sustain. Min. 2018, 17, 87-96. [CrossRef]

88. Lai, L.W. Effect of photochemical smog associated with synoptic weather patterns on cardiovascular and respiratory hospital admissions in metropolitan Taipei. Int. J. Environ. Health Res. 2012, 22, 287-304. [CrossRef] [PubMed]

89. Samet, J.M. Ozone and respiratory health the story continues. Am. J. Respir. Crit. Care Med. 2015, 192, 272-273. [CrossRef] [PubMed]

90. Zhang, J.; Chen, Q.; Wang, Q.; Ding, Z.; Sun, H.; Xu, Y. The acute health effects of ozone and PM 2.5 on daily cardiovascular disease mortality: A multi-center time series study in China. Ecotoxicol. Environ. Saf. 2019, 174, 218-223. [CrossRef]

91. Mukherjee, A.; Agrawal, M. World air particulate matter: Sources, distribution and health effects. Environ. Chem. Lett. 2017, 15, 283-309. [CrossRef] 
92. Liao, B.Q.; Liu, C.B.; Xie, S.J.; Liu, Y.; Deng, Y.B.; He, S.W.; Fu, X.P.; Fu, B.B.; Wang, Y.L.; Chen, M.H.; et al. Effects of fine particulate matter $\left(\mathrm{PM}_{2.5}\right)$ on ovarian function and embryo quality in mice. Environ. Int. 2020, 135, 105338. [CrossRef]

93. Zou, X.; Chen, K.; Zou, J.; Han, P.; Hao, J.; Han, Z. Single-cell RNA-seq data analysis on the receptor ACE2 expression reveals the potential risk of different human organs vulnerable to 2019-nCoV infection. Front. Med. 2020, 14, 185-192. [CrossRef]

94. Bunyavanich, S.; Do, A.; Vicencio, A. Nasal Gene Expression of Angiotensin-Converting Enzyme 2 in Children and Adults JAMA-J. Am. Med. Assoc. 2020, 323, 2427-2429. [CrossRef] [PubMed]

95. Zheng, K.I.; Feng, G.; Liu, W.-Y.; Targher, G.; Byrne, C.D.; Zheng, M.-H. Extrapulmonary complications of COVID-19: A multisystem disease? J. Med. Virol. 2021, 93, 323-335. [CrossRef] [PubMed]

96. Brooke, J.; Jackson, D. Older people and COVID-19: Isolation, risk and ageism. J. Clin. Nurs. 2020, 29, 2044-2046. [CrossRef] [PubMed]

97. Van Doremalen, N.; Bushmaker, T.; Morris, D.H.; Holbrook, M.G.; Gamble, A.; Williamson, B.N.; Tamin, A.; Harcourt, J.L.; Thornburg, N.J.; Gerber, S.I. Aerosol and surface stability of SARS-CoV-2 as compared with SARS-CoV-1. N. Engl. J. Med. 2020, 382, 1564-1567. [CrossRef] [PubMed]

98. Manisalidis, I.; Stavropoulou, E.; Stavropoulos, A.; Bezirtzoglou, E. Environmental and Health Impacts of Air Pollution: A Review. Front. Public Health 2020, 8, 14. [CrossRef] [PubMed]

99. Gupta, A.; Bherwani, H.; Gautam, S.; Anjum, S.; Musugu, K.; Kumar, N.; Anshul, A.; Kumar, R. Air pollution aggravating COVID-19 lethality? Exploration in Asian cities using statistical models. Environ. Dev. Sustain. 2020, 23, 6408-6417. [CrossRef] [PubMed]

100. Bourouiba, L. Turbulent Gas Clouds and Respiratory Pathogen Emissions: Potential Implications for Reducing Transmission of COVID-19. JAMA—J. Am. Med. Assoc. 2020, 323, 1837-1838. [CrossRef] [PubMed]

101. Sagawa, T.; Tsujikawa, T.; Honda, A.; Miyasaka, N.; Tanaka, M.; Kida, T.; Hasegawa, K.; Okuda, T.; Yatuka, K.; Takano, H. Exposure to particulate matter upregulates ACE2 and TMPRSS2 expression in the murine lung. Environ. Res. 2021, 195, 110722. [CrossRef]

102. Travaglio, M.; Yu, Y.; Popovic, R.; Selley, L.; Leal, N.S.; Martins, L.M. Links between air pollution and COVID-19 in England. Environ. Pollut. 2021, 268, 115859. [CrossRef] [PubMed]

103. Why Air Pollution Is Linked to a Faster Spread of Coronavirus-AirQualityNews. Available online: https://airqualitynews. com/2020/04/09/why-air-pollution-is-linked-to-a-faster-spread-of-coronavirus/ (accessed on 9 September 2021).

104. Urrutia-Pereira, M.; Mello-da-Silva, C.A.; Solé, D. COVID-19 and air pollution: A dangerous association? Allergol. Immunopathol. (Madr). 2020, 48, 496-499. [CrossRef]

105. Wu, X.; Nethery, R.C.; Sabath, B.M.; Braun, D.; Dominici, F. Exposure to air pollution and COVID-19 mortality in the United States: A nationwide cross-sectional study. medRxiv Prepr. Serv. Health Sci. 2005. [CrossRef]

106. Understanding the Link between COVID-19 Mortality and Air Pollution I American Lung Association. Available online: https: / / www.lung.org/blog/covid-19-mortality-and-air-pollution (accessed on 9 September 2021).

107. Air Pollution as Co-Factor of Covid-19 Mortality I Max-Planck-Gesellschaft. Available online: https://www.mpg.de/15952279/1 028-chem-099020-air-pollution-as-co-factor-of-covid-19-mortality (accessed on 9 September 2021).

108. Pozzer, A.; Dominici, F.; Haines, A.; Witt, C.; Münzel, T.; Lelieveld, J. Regional and global contributions of air pollution to risk of death from COVID-19. Cardiovasc. Res. 2020, 116, 2247-2253. [CrossRef]

109. Vasquez-Apestegui, B.V.; Parras-Garrido, E.; Tapia, V.; Paz-Aparicio, V.M.; Rojas, J.P.; Sanchez-Ccoyllo, O.R.; Gonzales, G.F. Association between air pollution in Lima and the high incidence of COVID-19: Findings from a post hoc analysis. BMC Public Health 2021, 21, 1161. [CrossRef] [PubMed]

110. Martelletti, L.; Martelletti, P. Air pollution and the novel Covid-19 disease: A putative disease risk factor. SN Compr. Clin. Med. 2020, 2, 383-387. [CrossRef]

111. Huang, C.; Wang, Y.; Li, X.; Ren, L.; Zhao, J.; Hu, Y.; Zhang, L.; Fan, G.; Xu, J.; Gu, X.; et al. Clinical features of patients infected with 2019 novel coronavirus in Wuhan, China. Lancet 2020, 395, 497-506. [CrossRef]

112. Hui, D.S.; Azhar, E.I.; Madani, T.A.; Ntoumi, F.; Kock, R.; Dar, O.; Ippolito, G.; Mchugh, T.D.; Memish, Z.A.; Drosten, C.; et al. The continuing 2019-nCoV epidemic threat of novel coronaviruses to global health-The latest 2019 novel coronavirus outbreak in Wuhan, China. Int. J. Infect. Dis. 2020, 91, 264-266. [CrossRef]

113. Wu, J.T.; Leung, K.; Leung, G.M. Nowcasting and forecasting the potential domestic and international spread of the 2019-nCoV outbreak originating in Wuhan, China: A modelling study. Lancet 2020, 395, 689-697. [CrossRef]

114. Cole, M.A.; Elliott, R.J.R.; Liu, B. The Impact of the Wuhan Covid-19 Lockdown on Air Pollution and Health: A Machine Learning and Augmented Synthetic Control Approach. Environ. Resour. Econ. 2020, 76, 553-580. [CrossRef]

115. Khan, R.; Kumar, K.R.; Zhao, T. The impact of lockdown on air quality in Pakistan during the covid-19 pandemic inferred from the multi-sensor remote sensed data. Aerosol Air Qual. Res. 2021, 21, 1-18. [CrossRef]

116. Hernández-Paniagua, I.Y.; Valdez, S.I.; Almanza, V.; Rivera-Cárdenas, C.; Grutter, M.; Stremme, W.; García-Reynoso, A.; RuizSuárez, L.G. Impact of the COVID-19 Lockdown on Air Quality and Resulting Public Health Benefits in the Mexico City Metropolitan Area. Front. Public Health 2021, 9, 1-19. [CrossRef] [PubMed]

117. Adams, M.D. Air pollution in Ontario, Canada during the COVID-19 State of Emergency. Sci. Total Environ. 2020, $742,140516$. [CrossRef] [PubMed] 
118. Baldasano, J.M. COVID-19 lockdown effects on air quality by $\mathrm{NO}_{2}$ in the cities of Barcelona and Madrid (Spain). Sci. Total Environ. 2020, 741, 140353. [CrossRef]

119. Selvam, S.; Muthukumar, P.; Venkatramanan, S.; Roy, P.D.; Manikanda Bharath, K.; Jesuraja, K. SARS-CoV-2 pandemic lockdown: Effects on air quality in the industrialized Gujarat state of India. Sci. Total Environ. 2020, 737, 140391. [CrossRef] [PubMed]

120. Kumari, P.; Toshniwal, D. Impact of lockdown measures during COVID-19 on air quality-A case study of India. Int. J. Environ. Health Res. 2020, 1-8. [CrossRef]

121. Beckerman, B.; Jerrett, M.; Brook, J.R.; Verma, D.K.; Arain, M.A.; Finkelstein, M.M. Correlation of nitrogen dioxide with other traffic pollutants near a major expressway. Atmos. Environ. 2008, 42, 275-290. [CrossRef]

122. Brugge, D.; Durant, J.L.; Rioux, C. Near-highway pollutants in motor vehicle exhaust: A review of epidemiologic evidence of cardiac and pulmonary health risks. Environ. Health A Glob. Access Sci. Source 2007, 6, 1-12. [CrossRef] [PubMed]

123. Kheirbek, I.; Haney, J.; Douglas, S.; Ito, K.; Matte, T. The contribution of motor vehicle emissions to ambient fine particulate matter public health impacts in New York City: A health burden assessment. Environ. Health A Glob. Access Sci. Source 2016, 15, 89. [CrossRef]

124. Lee, J.T.; Son, J.Y.; Cho, Y.S. Benefits of mitigated ambient air quality due to transportation control on childhood asthma hospitalization during the 2002 Summer Asian Games in Busan, Korea. J. Air Waste Manag. Assoc. 2007, 57, 968-973. [CrossRef]

125. Berman, J.D.; Ebisu, K. Changes in U.S. air pollution during the COVID-19 pandemic. Sci. Total Environ. 2020, $739,139864$. [CrossRef] [PubMed]

126. Ju, M.J.; Oh, J.; Choi, Y.H. Changes in air pollution levels after COVID-19 outbreak in Korea. Sci. Total Environ. 2021, 750, 141521. [CrossRef] 